\title{
A Review of Nursery Production Systems and \\ Their Influence on Urban Tree Survival
}

\begin{abstract}
Urban trees face a myriad of complex challenges growing in the built environment. The most common environmental conditions influencing urban tree mortality are water availability, nutrient deficiency and soil compaction. Long-term survival of recently installed trees has been directly attributed to site conditions, planting technique, and posttransplant maintenance. Tree survival is also dependent on selection of healthy, suitable plant material. Production methods for woody plants include traditional plastic containers (CG), pot-in-pot containers (PIP), and in-ground fabric containers (IGF). Alternatively, field grown trees may be produced as bare-root (BR) or root ball-excavated and burlapwrapped $(B \& B)$ trees. Each of these methods offers unique advantages in relation to production and installation. Many of the studies reviewed reveal varying post-transplant establishment and survival responses to production methods at a species-specific level.
\end{abstract}

Keywords: Container; Establishment; Field-Grown; Girdling Roots; Root Architecture

\section{Introduction}

Natural ecosystems are being lost or degraded by urbanization, with far-reaching consequences pertaining to species richness, environmental hydrological services, heat island effects, carbon sequestration, and nutrient cycling, among other important ecological processes (Nowak and Crane, 2002; Alberti and Marzluff, 2004; Oliveira et 
al., 2011). Studies have demonstrated that these urban centers may be improved through the implementation of urban greening initiatives that offer numerous ecological, social, and economic benefits (McPherson, 2007). Ecological benefits of urban greening include: lowering ambient air temperatures within urban heat islands, reducing atmospheric carbon dioxide, storm water capture and improving air quality (Nowak and Crane, 2002; McPherson, 2007; Oliveira et al., 2011). Urban greening also offers economic benefits to cities, such as reducing energy use and increasing heating/cooling cost savings, increasing property values and creating green industry jobs (McPherson, 2007; Nowak and Dwyer, 2007). A review of human health benefits in urban settings has suggested that there is a positive correlation between overall physical health in a population and the amount of accessible urban green space (van den Berg et al., 2015).

In a review of the efficacy of urban forest pollution mitigation, the term "urban forest" was used to describe the collection of all woody plants, lawns and "pervious soils" occurring in urban ecosystems where humans have installed these landscapes or have an influence on their continued protection (Escobedo et al., 2011). Trees are of particular importance for assessment of the benefits of the urban forest because the cost and effort of planning and installation, as well as the biology of tree growth, suggest a long-term investment and interest in their survival.

Many programs have been implemented to increase the number of trees planted in cities, including Iowa's collaborative program with the non-profit organization Trees Forever, Chicago's Urban Forest Climate Project, and the Million Trees LA initiative in Los Angeles, California (McPherson et al., 1994; Thompson et al., 2004; McPherson, 2014). In each location, urban trees are being planted in new and previously existing 
commercial, public, and residential landscapes. Planting spaces include garden beds, lawns, and street tree pits. Overall, results of these programs have been successful in regards to tree survival, growth, and ecological benefits (McPherson, 2014).

Municipalities may not have sufficient funding to cover installation, watering, and long-term maintenance costs for urban trees, and installed trees often don't survive longterm (Stobbart and Johnston, 2012). Tree survival in an urban setting depends on many factors, including planting location, installation, and post-planting care (Jutras et al., 2010). The most common environmental conditions influencing urban tree mortality relate to water stress, nutrient deficiency and soil compaction (Nowak et al., 1990). It has been found that early management and maintenance practices bear as much importance on tree establishment and survival as does the environmental conditions that they are grown in (Nowak et al., 1990). Trees that have been harvested from field-production methods are susceptible to transplant shock as a result of root loss during the harvesting process (Struve, 2009). Trees enduring transplant shock experience abiotic stress due to reduced water and nutrient uptake, and the loss of carbon energy stores (Struve, 2009). The physical spaces allotted to new tree plantings are restricted in urban settings, and the management and routine maintenance practices, including regular watering, are often performed at a minimum threshold or left to homeowners on adjacent land (Nowak et al., 1990).

In a meta-analysis of street tree survival rates found in multiple studies, the population half-life for trees installed into a street tree pit was found to be 13-20 years, and overall street tree life expectancy was found to be 19-28 years (Roman and Scatena, 2011). This survival period is longer than previous estimates of 7 or 13 -year average life spans, but 
without having a defined economic "break-even" point it is difficult to analyze whether the benefits are outweighing the costs (Moll, 1989; Skiera and Moll, 1992). An economic study of urban forest survival and growth revealed that the energy-saving benefits conferred by long-term planting programs in the city of Sacramento, California fell short of the projected savings values due to tree mortality (Ko et al., 2015). Due to the variability in urban tree care during and after planting, it is important to choose individual plants that have a high chance of survival, with minimal supplemental care required beyond the time of installation. Tree nursery production systems have been shown to influence post-transplant establishment and growth of trees (Levinsson, 2013), and thus may be an important parameter in choosing nursery stock relative to planting trees in the urban environment.

Young trees are generally produced using one of three main types of nursery production systems: container-grown (CG), field-grown root ball-excavated and burlapwrapped trees (B\&B), and field-grown bare-rooted trees (BR). The goal of developing each of these systems is to produce healthy nursery stock efficiently and cost-effectively. However, there are differences between these systems both in quality of plant material (particularly root development and subsequent transplanting viability), and affiliated costs (Green et al., 2015). Deeper insight into the effects of nursery production systems on tree morphological and physiological traits may aid in the development and implementation of best management practices to increase post-transplant establishment of urban trees. The intent of this paper is to review the current literature on the influence of nursery production systems prior to planting, and the potential impact of this variable on the performance and survivability of trees after installation in the urban environment. 


\section{Methods}

Research literature outlining nursery production systems, tree survivability, and urban tree performance was reviewed and compared. In the absence of sufficient findings to make direct comparisons between single-species plant performance in each production system, general observations of production system efficacy and long-term survival benefits, as well as plant species-specific responses were noted and compared. Information from professional journal sources was also included in the review. Emphasis was placed on shade trees commonly planted in urban settings in the northeastern United States, and other woody plant studies were also included for a more complete analysis, as appropriate. Plant nomenclature was verified using the Integrated Taxonomic Information System on-line database: http://www.itis.gov.

\section{Nursery Production Systems}

Several methods are currently in application relative to the production of woody plant material following initial cultivation of seedlings, cuttings, or tissue-cultured trees. These include transplanting liners (young plants) into various containerized systems including traditional (i.e. rigid) plastic containers (CG), pot-in-pot containers (PIP), and flexible in ground fabric containers (IGF). Trees can also be field grown and harvested as bare-root (BR) and root ball-excavated and burlap-wrapped (B\&B) trees. Each of these methods offers unique advantages and disadvantages in relation to production and installation. Container-Grown (CG) Systems

Container-grown systems include traditional plastic containers and other designs (see Fig. 1), which have been developed for ease of handling, appearance, improved drainage and elimination of circling root systems (Appleton, 1993). Due in likelihood to the 
protection provided by the plastic container and use of lightweight soilless growing media, standard containerized nursery stock is less susceptible to mechanical or humaninduced injury sustained in the nursery or during transport as compared to B\&B plants (Mathers et al., 2007). Though traditional containers are cost-effective, concerns have arisen about the negative influence of circling tree root development on drought stress tolerance, nutrient uptake capacity, and anchorage, leading to decreases in long-term survivability (Warren and Blazich, 1991). In order to address these physiological disadvantages, a number of newer designs and technologies have been implemented in the production of containerized trees. Improved designs include variably-shaped (i.e. square; pyramidal) containers, and features such as drainage holes, and ribbed or stepped plastic, to minimize circling root growth (Appleton, 1989, 1993). Container-grown nursery stock retains $100 \%$ of the root system at the time of planting, in comparison to B\&B plants, which may be transplanted with as little as $5 \%$ of the original root system (Blessing and Dana, 1987). However, this estimate does not reflect concerns associated with root deformation and necessary pre-transplant pruning, nor does this ensure higher post-transplant survival rates.

Advancements in container production include the incorporation of air pruning to increase fine root biomass and lateral shoot growth. Air pruning containers feature holes that allow pockets of air to contain root growth inside the container and kill growing root tips to promote fine root biomass and branching (Amoroso et al., 2010). Air-Pot ${ }^{\mathrm{TM}}$ cylindrical plastic containers (Caledonian Tree Company, Ltd., Scotland) utilize air root pruning and have been shown to minimize circling root growth and other root deformations in Acer rubrum L. 'Florida Flame', Ulmus minor Mill. (syn. Ulmus procera 
Salisb.), and Tilia cordata Mill. (Amoroso et al., 2010; Gilman et al., 2010a).

$\{$ Fig. 1\}

In-ground fabric (IGF) containers (see Fig. 2), originally developed by Reiger and Whitcomb, have been repeatedly modified and improved in commercial-scale nursery production (Appleton, 1995). These containers are made of flexible fabric and sometimes include a clear polyethylene base (Cole et al., 1998). In-ground fabric-grown root balls may retain the same density of roots (Fig. 3) in half of the volume of B\&B root balls. Warren and Blazich (1991) found that IGF containers significantly reduced circling root growth in several woody plant species compared to CG stock. One study using three-year old Pinus elliottii Engelm. seedlings showed that the trees were slower to establish when transplanted into the ground as CG stock than IGF or B\&B trees (Beeson and Gilman, 1992). Another experiment compared post-transplant establishment of IGF and B\&Bproduced Ilex x attenuata Ashe 'East Palatka', and results indicated that IGF-grown plants showed signs of abiotic stress and low photosynthetic activity during establishment, thus requiring more irrigation than field grown trees after transplanting (Harris and Gilman,1993). In-ground fabric containers do not offer the same level of protection during production, transportation, and installation as do traditional containers (Appleton, 1995; Cole et al., 1998). The initial investment cost of IGF containers may be a barrier for growers considering the adoption of this practice, though IGF systems have been found to grant cost savings in harvest, transport, and planting-associated costs compared to B\&B (Green et al., 2015).

$\{$ Fig. 2\}

In a study comparing several CG designs with an IGF container, Buxus microphylla 
Siebold \& Zucc., Salix nigra Marshall, Pinus strobus L., and Koelreuteria paniculata Laxm. showed reduced circling root growth when grown in IGF and a stepped-pyramid container design as compared to the other CG designs (Appleton, 1989). However, in the same study Lonicera pileata Oliv. and Rhododendron L. 'Hershey's Red' did not develop circling roots in IGF or traditional containers, instead establishing a fine fibrous root system (Appleton, 1989). These results suggest an interaction at the species-specific level, which indicates that some production systems may be advantageous over others for increasing tree establishment and survival.

A study of four CG designs compared root and shoot growth of Rhododendron L. 'Delaware Valley White', Ilex crenata Thunb. 'Green Luster', Juniperus horizontalis Moench 'Plumosa Compacta Youngstown', and Viburnum plicatum Thunb. f. tomentosum 'Shasta'. Traditional containers, stepped pyramidal containers, square containers and IGF containers were used. It was shown that the stepped pyramidal containers, square containers and IGF containers significantly reduced circling root growth in all four plant species compared to traditional containers (Warren and Blazich, 1991). Plants were installed in a landscape after one and two years in containers, and shoot and root dry weights were measured after 16 weeks in the landscape setting. The authors measured above-ground plant tissue as well as root tissue shaved from the original root ball. Shoot to new root ratios showed variation by plant species after one or two years' production in containers. This study provided useful information concerning root growth tendencies in different containerized systems, and also demonstrates the difficulty in comparing the effects of these production systems across several species with varying root system morphologies. 
Pot-in-pot (PIP) container systems consist of plant material grown in a plastic "liner" container, which is placed inside a permanent in-ground "socket" container (Mathers, 2003). This system can also be utilized above-ground (Appleton, 1995). Pot-in-pot systems can be advantageous compared to traditional container systems, due to an apparent reduction in heat damage sustained by plant roots (Appleton, 1995). Air space between the two pots reduces thermal heating of soil and heat kill of roots during the summer, and this temperature buffering effect increases root survival during the winter (Appleton, 1995; Kirk et al., 2004). These systems can also minimize damage from blowover, and help to minimize loss of substrate, fertilizer, and herbicide amendments (Appleton, 1995). This system can increase survival and vigor of healthy plant material during production, though the initial costs of installation may be a deterrent to some growers. The liner pot is constructed from rigid plastic, and so the root systems of plants produced using this system may be subject to species-specific circling tendencies similar to other CG nursery stock (as seen in Fig. 3) (Appleton, 1989; Warren and Blazich, 1991). Otherwise, the PIP system offers the same post-transplant survival benefits as other CG systems, including protection from pre-transplant injury and retention of the root system.

Another benefit of containerized systems is that container materials can be treated with copper hydroxide root growth-regulating products such as SpinOut ${ }^{\mathrm{TM}}$ (Griffin Corp., Inc., Valdosta, GA). These products are used to chemically prune roots in nursery production systems to reduce malformed root-systems, increase fine root biomass, and improve post-transplant survival (Appleton, 1995; Gilman et al., 2010b; Struve, 1993). Chemical pruning approaches have been reported to be effective for containing root 
growth or preventing circling root development, and do not appear to be detrimental to post-transplant establishment (Appleton, 1995).

\section{Field-Grown Nursery Production}

Trees grown in a production field can be harvested BR or B\&B. The B\&B root ball excavation process can leave as much as $95 \%$ of the tree's total root system in the field, with up to $30 \%$ of what is left in the field estimated to be fine root mass (Blessing and Dana, 1987; Mathers et al., 2007). This can be detrimental due to the loss of fine root biomass, which is critical for water and nutrient acquisition (Yin et al., 2014). Fieldgrown BR production of trees requires removal of the soil from the root system, and can be economically advantageous to the grower due to the elimination of container costs, retention of field soil, and decreased water use (Reiger and Whitcomb, 1982; Harris and Gilman, 1993; Richardson-Calfee and Harris, 2005). Bare-root trees may require further

preventative measures such as root-dipping in hydrogel (a hydrophilic absorbent polymer substance) to prevent root desiccation following harvest (Buckstrup and Bassuk, 2000; Landis and Haase, 2012). Bare-root and B\&B plants are often larger at the time of transplanting than containerized nursery stock, but may sustain greater mortality rates compared to smaller trees due to a number of production-based practices (Struve, 2009). One study showed that large-caliper Quercus rubra L. transplanted alongside smallercaliper trees produced significantly more caliper growth four years after transplanting, though only $42 \%$ of the larger trees survived as compared with $100 \%$ of the smaller trees (Struve et al., 2000). This is contrary to the commonly accepted hypothesis that larger trees will grow more slowly than smaller trees, after installation. However, smaller-sized Quercus virginiana Mill. demonstrated increased rates of stem and height growth as 
compared to larger trees, which supports the idea that larger trees will take more time to re-establish shoot-to-root growth ratios following transplanting (Gilman et al., 1998; Watson, 1985). One possible explanation of the factors influencing tree size discrepancies in establishment variation may be Struve's hypothesis of larger nursery stock as the so-called genetic "runts" of their populations, harvested larger and later because they did not reach salable size at the time of the initial harvest (Watson, 1985; Struve, 2009; Yin et al., 2014).

Plants harvested BR have the highest success in establishment when transplanting occurs in the narrow windows of tree dormancy between soil thawing and bud break in the spring, and leaf drop and soil freezing in the fall (Harris and Bassuk, 1994; Watson and Himelick, 2013; Struve, 2009). Bare-root trees can suffer reduced rates of establishment as compared to containerized and B\&B plants, and BR plants are more vulnerable during transport due to the risk of root desiccation without the protection of moisture-retaining soil, necessitating treatment with anti-desiccants or additional irrigation (Struve, 2009). Sundström and Keane (1999) found that CG Pseudotsuga menziesii Mirb. had a higher percentage of survival than BR trees (of which $80-90 \%$ of trees survived) ten years after planting, though this slight advantage was not statistically significant. Buckstrup and Bassuk (2000) compared growth responses of B\&B and BR trees, transplanted in the spring and the fall into urban "tree lawns" ranging from 5-15 feet in width. The trees examined in this experiment were Celtis occidentalis L., Ostrya virginiana (Mill.) K. Koch, and Quercus bicolor Willd. When transplanted in the fall, $C$. occidentalis fared better when produced by $\mathrm{BR}$ compared to $\mathrm{B} \& \mathrm{~B}$. However, $\mathrm{B} \& \mathrm{~B} C$. occidentalis out-performed BR trees when transplanted in the spring. All species and 
treatments fared well with few significant differences after the first year (Buckstrup and Bassuk, 2000). This study confirmed the viability of using BR production as an alternative to $\mathrm{B} \& \mathrm{~B}$ during the fall transplanting season for these common urban tree species.

Watson and Himelick note that field-grown B\&B trees generally establish more quickly than container-grown trees (Watson and Himelick, 2013). As with the other nursery production systems reviewed, B\&B trees may have relative advantages or disadvantages, including being able to source larger plant material at the time of installation (Harris and Bassuk, 1993). Comparison of production and planting costs of Q. bicolor and $Q$. rubra revealed that B\&B nursery stock was shown to cost on average \$11.01 per tree for preparation, loading and unloading, and planting, while PIP, IGF, and BR trees cost significantly less per tree $(\$ 6.52, \$ 5.38$, and $\$ 4.38$, respectively) (Green et al., 2015). Trees harvested B\&B also require a higher cost for harvesting as compared to IGF and PIP systems, and removal of soil from the field production sites raises long-term environmental concerns related to sustainability (Lass and Neal, 2014; Neal and Lass, 2014). As B\&B is a common method of nursery production, it does offer specific advantages, including widespread availability of plant materials during the spring and fall. Though B\&B trees are planted with only a fraction of their original roots systems intact, the quality of roots present may be superior. According to Neal and Lass (2014), "the strong radial distribution of structural roots observed in field-grown trees is purported to be the best structure for long-term tree health" (see Fig. 3).

\{Fig. 3\}

Other Production Methods 
Additional production techniques have been developed in order to mitigate the influence of nursery production on survivability and limit transplant shock, including root pruning and undercutting of seedlings or early root-cuttings. The timing of transition between propagation (i.e. field-grown liners) to production and cultivation systems can effect root development as well; in Sweden it has been reported that moving young fieldgrown nursery stock into containerized systems up to two years prior to transplanting increases fine root biomass (Levinsson, 2013). Pre-establishing methods also expose plants to transplant stress while still under a heavy management regime, which is thought to prepare them to better withstand transplant shock in the future (Struve, 2009; Levinsson, 2013). The Missouri gravel bed system, in which trees are heeled in to a gravel mulch substrate, can be utilized for BR and B\&B trees for easier handling and extended transplanting times (Starbuck et al., 2005; Struve, 2009). Transplant timing plays a role in tree survivability following installation, and in a study $Q$. bicolor and Quercus macrocarpa Michx., optimal transplant-timing varied for each species (Yin et al., 2014). In addition to extending the transplanting period, the Missouri gravel bed system may be advantageous for cultivation of difficult-to-transplant trees or larger bareroot specimens, with higher survival and growth rates observed using this technique to heel in Fraxinus pennsylvanica Marsh. 'Summit' and Q. rubra prior to summer transplanting (Struve, 2009). This system has been shown to encourage root regeneration and reduce transplant shock, and requires larger transplanting space for installation, which may aid further in establishment (Starbuck et al., 2005).

\section{Production System Influence on Survivability}

The impacts of nursery production systems on tree development and transplant 
success have been examined previously (Ferrini et al., 2000; Levinsson, 2013; Neal and Lass, 2014; Gilman et al., 2016). Varying results across systems and species confounds comparisons, and the economic implications of each system may outweigh the benefits of implementation depending on the influence of interconnected survival factors. One of the most critical aspects of tree establishment and survival is maximal utilization of the root system that is retained by the plant upon transplanting from the nursery to the final site (Hirons and Percival, 2012). Root characteristics are shown to be affected by production systems, and so this may be one mechanism of production system influence on tree establishment and survival.

\section{Nursery Production System Impacts on Root architecture}

The term "root architecture" refers to the three-dimensional arrangement of the root system, which, along with fine root biomass, affects water and nutrient acquisition capacity, hydraulic conductance, and is responsible for stabilization of trees in the soil (Lynch, 1995). Production systems have been shown to have a great influence on root architecture, particularly in containerized systems, in which root systems begin growing in an encircled pattern (see Fig. 3) as they develop against container walls (Gilman and Harchick, 2014; Gilman et al., 2015). Trees with circling roots are in danger of developing stem-girdling roots, which were reported to occur in 52\% of landscape trees examined in one survey (Johnson and Hauer, 2000). Lateral root production was negatively influenced after production in field-grown systems, and adventitious root development in response lead to a deeper root flare in the soil (Hewitt and Watson, 2009). This production impact can influence survivability due to the lack of lateral roots and the increased likelihood of transplanting with excessive soil on top of the roots 
(Gilman and Harchick, 2008). Hewitt and Watson (2009) found that root pruning practices typical in BR liner production encouraged deeper root systems, which may offer an advantage in drought-stress conditions, as they are able to access water in the lower soil substrate (Pinheiro et al., 2005). However, deeper root systems have also been shown to decrease establishment rates and long-term survival, and are not preferable for landscape planting (Hewitt and Watson, 2009). Neal and Lass (2014) suggest that B\&B generates ideal root architecture in terms of radially-distributed roots, and therefore may confer a survivability advantage.

\section{Nursery Production System Impacts on Fine Root Hydraulic Conductance}

Fine root biomass has been linked to increased establishment and survival, and fine root hydraulic conductance is critical for maintaining an adequate supply of water after transplanting (Lynch, 1995). Root-pruned Q. macrocarpa and Q. bicolor demonstrated a positive correlation between fine root hydraulic conductance and post-transplant recovery, and yielded species-specific responses related to vigor (Yin et al., 2014). Root pruning incurred a greater negative impact on fine root hydraulic conductance in $Q$. macrocarpa than in $Q$. bicolor, as $Q$. bicolor recovered more rapidly based on shoot growth measurements. Larger-caliper trees also demonstrated this species-specific response, with $Q$. macrocarpa suffering post-transplant stress effects more severely than Q. bicolor based on visible evidence of post-transplant shock, as well as quantifiable fine root regeneration and hydraulic conductance. Neal and Lass (2014) found that Betula nigra L. root systems harvested from IGF systems contained approximately the same root biomass as those roots harvested from field-grown and PIP systems (similar results would be expected in other CG systems without design improvements), but the distribution of 
classes of roots assigned by diameter varied between the systems. Container-grown trees had the highest distribution of fine roots at 45\%, IGF tree root systems contained 17\% fine roots, and field-grown trees featured 14\% fine roots (Neal and Lass, 2014). Though the root architecture in these systems varied (as depicted in Fig. 3), the increase in fine root biomass could be advantageous for water use efficiency, nutrient uptake, and stabilization (Lynch, 1995).

Nursery Production System Influence on Stem Girdling Root Production

The formation of girdling roots (both stem-girdling and root-girdling) has a significant impact on long-term tree survivability (Johnson and Hauer, 2000). Development of girdling roots in containerized systems is species-specific, as evidenced by the fine, fibrous root growth of $L$. pileata and $R$. 'Hershey's Red' (Appleton, 1989). It has been recommended to disturb the root ball of trees before planting in order to refigure root configuration and prevent stem girdling root formation, though results based on these recommendations have been variable (Johnson and Hauer, 2000; Weicherding et al., 2007). Stem girdling roots lead to tree structural and physiological defects that can impact tree survival (Johnson and Hauer, 2000). Although container-grown trees may be more likely to develop circling roots as plants mature, it has been found that stemgirdling roots do not necessarily continue to grow circuitously after planting (Struve, 1990).

Several factors can influence stem-girdling root formation, but planting depth (burial of the root collar) has been documented as a primary contributing factor (see Fig. 4) (Wells et al., 2006; Day et al., 2008). Stem-girdling root development in A. rubrum 'October Glory' increased from 14\% ( $\pm 19 \%)$ of the trunk circumferentially surrounded 
by girdling roots in the control trees to $48 \%( \pm 29 \%)$ when the root flare was planted 6 inches below grade, and stem girdling root coverage increased to $71 \%( \pm 21 \%)$ when planting was 12 inches below grade (Wells et al., 2006). However, there was not a significant difference in Prunus yedoensis Matsum. girdling root formation under the same planting depth treatments (Wells et al., 2006). Air root-pruning containers have been shown to reduce the occurrence of circling root growth, though there is no evidence of any one type of container that eliminates root defects or produces a plant with improved root architecture, overall (Gilman et al., 2016).

$\{$ Fig. 4$\}$

Nursery Production System Influence on Tree Establishment and Plant Growth Response

Trees are considered to have achieved "establishment" following transplanting once normal physiological processes return to pre-transplant rates (Watson, 1985).

Specifically, shoot-to-root elongation ratios, shoot elongation rates, or shoot xylem water potentials are examined to determine establishment rates (Struve, 2009). Amoroso et al. (2010) found that shoot biomass of $T$. cordata and U. minor were not significantly affected by container design after one year of production, and only one container design caused a significant reduction in root biomass of $T$. cordata, while $U$. minor trees were not impacted. There was a significant negative effect on chlorophyll content in $T$. cordata grown in air root-pruning containers as compared to those grown in traditional containers, which indicates physiological stress incurred by container type (Amoroso et al., 2010). Buckstrup and Bassuk (2000) found that spring-planted C. occidentalis shoot growth, leaf canopy and leaf area all had increased growth in B\&B trees compared to BR trees, with leaf canopy measurements remaining significantly greater in the second year. 
Fall-planted C. occidentalis did not follow this growth pattern, but spring-planted $O$. virginiana and $Q$. bicolor also demonstrated favorable growth responses when harvested B\&B in comparison to BR (Buckstrup and Bassuk, 2000). Buckstrup and Bassuk found that their results indicated that $\mathrm{B} \& \mathrm{~B}$ production leads to faster establishment and reduced transplant stress compared to BR, though overall survivability results suggest both methods were viable for transplanting the three species (with the caveat that BR nursery stock was root-dipped to prevent desiccation).

Nursery Production System Influence on Post-Transplant Irrigation Requirements

Drought stress tolerance has been found to significantly impact transplant recovery rates, and production practices such as root pruning that are typically employed to stimulate fine root development prior to transplanting can also be applied to alleviate drought stress during the weeks directly following planting (Beeson and Gilman, 1992). P. elliottii produced B\&B and IGF established more quickly than CG trees, which was influenced by an increase in root development and elongation into the planting area by the B\&B and IGF trees (Beeson and Gilman,1992). However, the transplanted trees were irrigated daily for fourteen weeks after planting, which could have aided in more rapid establishment rates for the transplanted trees compared to the control trees, which were watered every other day. Gilman (2001) found that root-pruned B\&B nursery stock offered the highest survivability when transplanted into landscapes with "limited" irrigation programs. Quercus virginiana Mill. trees grown in several different CG and field production systems had a $100 \%$ percent survival rate one year after transplanting into a field if they received bi-weekly irrigation during the first year after planting occurred (Gilman, 2001). If $Q$. virginiana in this study did not receive the full irrigation 
regimen, but instead were irrigated for only six weeks after planting, survival rate dropped to 57\%, with the most losses from CG trees (Gilman, 2001). Variation in irrigation and water availability for newly-planted urban trees is directly related to tree establishment and survivability, and it has been found that more frequent irrigation as opposed to a greater volume of water confers greater survival benefits (Gilman et al., 1998). In the event that frequent irrigation is not available for newly-planted trees, choosing nursery stock with increased survivability traits based on production practice will help to decrease losses prior to establishment.

\section{Production System Influences on Tree Survival based on Nutrient Uptake Capacity}

Urban soils are often nutrient-deficient and may harbor contaminants, such as de-icing salts, heavy metals, and other products related to human and industrial activity (Day et al., 2010a). There is increasing interest in using urban tree planting for phytoremediation, as well as other efforts to help ameliorate the negative effects of urbanization on soils, but little is known about the difficulty of growing trees in inhospitable urban soils (Day et al., 2010a).

Root architecture and size distribution has been shown to be affected by production systems in several species (Gilman and Harchick, 2008; Neal and Lass, 2014). A proliferation of fine roots is advantageous for increased levels of nutrient uptake and assimilation, and is necessary for establishing and maintaining mycorrhizal symbioses (Day et al., 2010b). Given that changes in root morphology and root order distribution and water and nutrient uptake ability can be influenced by production system, it may be possible to find a positive correlation in production system impact on tree survivability based on factors including nutrient uptake capacity. 


\section{Nursery Production System Influence on Pest and Pathogen Susceptibility}

It is hypothesized that the impact of future changes in climate will increase physiological stress on trees in the urban environment, and therefore predispose urban plantings to pest and pathogen attack (Tubby and Webber, 2010). Additionally, the changing urban environment may become more hospitable for pests and pathogens leading to increased pressures and new introductions (Tubby and Webber, 2010). Nursery production systems can further influence tree susceptibility. For example, the occurrence of stem-girdling roots can lead to tissue death, creating a potential infection site for wood decay fungi (Johnson and Hauer, 2000). Drought-stressed plants are more susceptible to insect damage, due in part to the physiological changes sustained by the plant, including higher levels of nitrogen and depleted energy stores, ultimately reducing defense responses (Mattson and Haack, 1987). Drought stress often occurs during high temperature periods, which are thought to be more suitable for insect and pathogen survival (Mattson and Haack, 1987). Drought stress is frequently correlated with increasing pathogen damage, particularly by cankering and wilt fungi, due to the alteration of host physiological responses under dual abiotic and biotic stress conditions (Desprez-Loustau et al., 2006). Because nursery production methods alter drought stress tolerance and physiological responses in trees, the choice of production systems may be significant for reducing the occurrence of pest and pathogen damage on urban trees.

\section{Discussion}

Nursery production systems impact plant development and root architecture, which offer relative advantages and disadvantages (see Table 1) and may directly influence long-term plant survivability (Gilman et al., 2003; Levinsson, 2013). 
Without more long-term studies of tree survival after establishment, it is difficult to conclude if a given production system results in an increase in survival rate. Factors confounding a thorough comparison of each nursery production system include age and size of the tree at the time of experimentation, differing growing environments, and differences in species-specific responses to production systems. The size of nursery stock used at transplant has an effect on the rate of establishment, and several studies have shown that smaller trees will establish more rapidly than larger trees, as discussed by Watson (1985) and Struve (2009). However, other factors may hinder these rates over time, so there is no conclusive evidence as of yet to determine that smaller trees will in fact consistently outgrow larger trees (Watson, 2005).

Post-transplant survival of trees can also be impacted by transplant timing and techniques (particularly initial planting depth), which can be variable and highly influenced by both production system and practitioner. Factors affecting tree transplant survival and establishment include improper handling, site environmental variables, planting techniques, and post-transplant maintenance, all of which are integral to initial tree survival and long-term success (Struve, 2009). Nursery growers, urban foresters, tree wardens, and others in similar roles would be well-served by a decision-making matrix that could utilize known data and help produce and select plant material with the highest probability of post-transplant survival and cost returns. For example, the literature suggests that managers of landscapes with reduced irrigation programs may be able to improve survivability rates for new plantings by sourcing root-pruned B\&B nursery stock (this result was obtained using Q. virginiana) (Gilman, 2001). Similarly, urban foresters and landscape managers interested in transplanting $Q$. rubra or $F$. pennsylvanica during 
the summer months would achieve the best establishment and survivability results by using BR stock produced in a Missouri gravel bed system (Starbuck et al., 2005).

Nursery production practices may also impact a plant's ability to tolerate water stress and influence pest and disease susceptibility, which can further reduce survivability (Beeson and Gilman, 1992; Tubby and Webber, 2010). These survival factors are highly interactive and often interdependent, and thus more research will be required to parse the individual impacts of nursery production systems and practices. It would seem that if root architecture was the single limiting factor pertaining to long-term survivability, there would be a more distinct disparity in survival of traditional containerized trees when compared to other methods. In the absence of these results, however, it may be true that the most critical aspects of long-term survival will be the management of trees posttransplant, with production systems contributing to tree health during establishment more greatly than solely influencing long-term survival.

\section{$\{$ Table 1$\}$}

\section{Conclusions}

This review of the existing literature revealed a complicated interaction between nursery production systems, tree species, and site conditions that ultimately influence the success of tree establishment and performance. Nursery production systems appear to impact survivability traits including drought tolerance, pest and disease susceptibility, and rates of tree establishment, primarily - though not surprisingly - through their influence on root architecture and growth. Production systems that encourage the growth and development of fine roots, for example, may produce trees with slower establishment rates after planting, or an increased susceptibility to lack of water. This is of particular 
relevance to practitioners charged with the installation of large numbers of trees in dry years, or in locations with serious water restrictions. Production systems that encourage irregular root growth may potentially compromise a tree's ability to mature and increase in size in later years, as roots continue to enlarge in an aberrant and potentially restrictive manner.

Nursery production systems may also impact planting practices, like depth of installation, and influence how plant material is handled. Since large numbers of trees continue to be installed in urban landscapes with excessive soil on their roots, this has obvious applications relative to current planting practices. Without more long-term survival studies and side-by-side comparisons of production practices, findings seem to indicate that varying production systems offer species-specific effects relative to tree establishment and survivability.

\section{Acknowledgements}

We would like to thank the following individuals and organizations: D. Lass (University of Massachusetts); C. Neal (University of New Hampshire); A. Snow (Town of Amherst); J. Kinchla (Amherst Nurseries). This work was supported by the USDA National Institute of Food and Agriculture - McIntire Stennis Project \# 25, Accession $\# 1000762$.

\section{Literature Cited}

Alberti, M., Marzluff, J.M., 2004. Ecological resilience in urban ecosystems: linking urban patterns to human and ecological functions. Urban Ecosystems 7, 241-265. doi:10.1023/B:UECO.0000044038.90173.c6

Amoroso, G., Frangi, P., Piatti, R., Ferrini, F., Fini, A., Faoro, M., 2010. Effect of 
container design on plant growth and root deformation of littleleaf linden and field elm. HortScience 45, 1824-1829.

Appleton, B.L., 1993. Nursery production alternatives for reduction or elimination of circling tree roots. Journal of Arboriculture 19, 383-388.

Appleton, B.L., 1989. Evaluation of nursery container designs for minimization or prevention of root circling. Journal of Environmental Horticulture 7, 59-61.

Appleton, B.L., 1995. Nursery production methods for improving tree roots -an update. Journal of Arboriculture 21, 265-270.

Beeson, R.C., Gilman, E.F., 1992. Diurnal water stress during landscape establishment of slash pine differs among three production methods. Journal of Arboriculture 18, $281-287$.

Blessing, S.C., Dana, M.N., 1987. Post-transplant root system expansion in Juniperus chinensis $\mathrm{L}$. as influenced by production system, mechanical root disruption and soil type. Journal of Environmental Horticulture 5, 155-158.

Buckstrup, M. J., Bassuk, N. L., 2000. Transplanting success of balled-and-burlapped versus bare-root trees in the urban landscape. Journal of Arboriculture 26, 298-308.

Cole, J.C., Kjelgren, R., Hensley, D.L., 1998. In-ground fabric containers as an alternative nursery crop production system. HortTechnology 8, 159-163.

Day, S.D., Harris, J.R., 2008. Growth, survival, and root system morphology of deeply planted Corylus colurna 7 years after transplanting and the effects of root collar excavation. Urban Forestry \& Urban Greening 7, 119-128.

doi:10.1016/j.ufug.2007.12.004 
Day, S.D., Wiseman, P.E., Dickinson, S.B., Harris, J.R., 2010a. Contemporary Concepts of Root System Architecture of Urban Trees. Arboriculture \& Urban Forestry 36, 149-159. doi:10.1111/j.1469-8137.2008.02648.x

Day, S.D., Wiseman, P.E., Dickinson, S.B., Harris, J.R., 2010b. Tree root ecology in the urban environment and implications for a sustainable rhizosphere. Arboriculture \& Urban Forestry 36, 193-205.

Desprez-Loustau, M.L., Marçais, B., Nageleisen, L.M., Piou, D., Vannini, A., 2006. Interactive effects of drought and pathogens in forest trees. Annals of Forest Science 63, 597-612. doi:10.1051/forest:2006040

Escobedo, F.J., Kroeger, T., Wagner, J.E., 2011. Urban forests and pollution mitigation: analyzing ecosystem services and disservices. Environmental Pollution 159, 20782087. doi:10.1016/j.envpol.2011.01.010

Ferrini, F., Nicese, F.P., Mancuso, S., Giuntoli, A., 2000. Effect of nursery production method and planting technique on tree establishment in urban sites: preliminary results. Journal of Arboriculture 26, 281-284.

Gilman, E.F., 2001. Effect of nursery production method, irrigation, and inoculation with mycorrhizae-forming fungi on establishment of Quercus virginiana. Journal of Arboriculture 27, 30-39.

Gilman, E.F., Black, R.J., \& Dehgan, B., 1998. Irrigation volume and frequency and tree size affect establishment rate. Journal of Arboriculture 24, 1-9.

Gilman, E.F., Grabosky, J., Stodola, A., Marshall, M.D., 2003. Irrigation and container type impact red maple (Acer rubrum L .) 5 years after landscape planting. Journal of Arboriculture 29, 231-236. 
Gilman, E.F., Harchick, C., 2014. Root system morphology influences lateral stability of Swietenia mahagoni. Arboriculture \& Urban Forestry 40, 27-35.

Gilman, E.F., Harchick, C., 2008. Planting depth in containers affects root form and tree quality. Journal of Environmental Horticulture 26, 129-134.

Gilman, E.F., Harchick, C., Paz, M., 2010a. Effect of container type on root form and growth of red maple. Journal of Environmental Horticulture 28, 1-7.

Gilman, E.F., Paz, M., Harchick, C., 2016. Effect of eight container types and root pruning during nursery production on root architecture of Acer rubrum. Arboriculture \& Urban Forestry 42, 31-45.

Gilman, E.F., Paz, M., Harchick, C., 2015. Retention time in three nursery container volumes impacts root architecture. Arboriculture \& Urban Forestry 41, 146-154.

Gilman, E.F., Paz, M., Harchick, C., 2010b. Root ball shaving improves root systems on seven tree species in containers. Journal of Environmental Horticulture 28, 13-18.

Green, B.L., Harper, R.W., Lass, D.A., 2015. Differing nursery production systems impact cost of planting oak species in the urban environment. HortTechnology 25, $651-656$.

Harris, J.R., Bassuk, N.L., 1993. Tree Planting Fundamentals. Journal of Arboriculture 19, 64-70.

Harris, J.R., Bassuk, N.L., 1994. Seasonal Effects on Transplantability of Scarlet Oak, Green Ash, Turkish Hazelnut and Tree Lilac. Journal of Arboriculture 20, 310317.

Harris, J.R., Gilman, E.F., 1993. Production method affects growth and posttransplant establishment of East Palatka holly. Journal of the American Society for 
Horticultural Science 118, 194-200.

Hewitt, A., Watson, G., 2009. Bare root liner production can alter tree root architecture. Journal of Environmental Horticulture 27, 99-104.

Hirons, A.D., Percival, G.C., 2012. Fundamentals of tree establishment: a review. Trees, People and the Built Environment 51-62.

Johnson, G.R., Hauer, R.J., 2000. A practitioner's guide to stem girdling roots of trees. University of Minnesota Extension Service, St. Paul.

Jutras, P., Prasher, S.O., Mehuys, G.R., 2010. Appraisal of key abiotic parameters affecting street tree growth. Arboriculture \& Urban Forestry 36, 1-10.

Kirk, S.D., Starbuck, C.J., Van Sambeek, J.W., 2004. Missouri gravel bed and a pot-inpot system superior to white polyethylene and foam for overwintering Syringa. Combined Proceedings International Plant Propagators' Society 54, 132-137.

Ko, Y., Lee, J.H., McPherson, E.G., \& Roman, L.A., 2015. Long-term monitoring of Sacramento Shade program trees: Tree survival, growth and energy-saving performance. Landscape and Urban Planning 143, 183-191. doi:10.1016/j.landurbplan.2015.07.017

Landis, T.D., Haase, D.L., 2012. Applications of hydrogels in the nursery and during outplanting. Forest and Conservation Nursery Associations-2011, (PMRSP-68), 53-58. Retrieved from http://www.fs.fed.us/rm/pubs/rmrs_p068/rmrs_p068_053_058.pdf

Lass, D.A., Neal, C., 2014. Getting to the roots: costs of growing river birch in different production systems. American Nurseryman (August), 12-18.

Levinsson, A., 2013. Post-transplant shoot growth of trees from five different production 
methods is affected by site and species. Arboriculture \& Urban Forestry 39, $201-$ 210.

Lynch, J., 1995. Root architecture and plant productivity. Plant Physiology 109, 7-13. doi:10.1104/pp.109.1.7

Mathers, H.M., 2003. Summary of temperature stress issue in nursery containers and current methods of protection. HortTechnology 13, 617-624.

Mathers, H.M., Lowe, S.B., Scagel, C., Struve, D.K., Case, L.T., 2007. Abiotic factors influencing root growth of woody nursery plants in containers. HortTechnology $17,151-162$.

Mattson, W.J., Haack, R.A., 1987. The role of drought in outbreaks of plant-eating insects. BioScience 37, 110-118.

McPherson, E.G., 2014. Monitoring million trees LA: tree performance during the early years and future benefits. Arboriculture \& Urban Forestry 40, 285-300.

McPherson, E.G., Simpson, J.R., Peper, P.J., Gardner, S.L., Vargas, K.E., Xiao, Q., 2007. Northeast community tree guide: Benefits, costs, and strategic planting. U.S. Department of Agriculture, Forest Service Pacific Southwest Research Station, Albany, CA .

McPherson, E.G., Nowak, D.J., Rowntree, R.A, 1994. Chicago's urban forest ecosystem: results of the Chicago urban forest climate project. U.S. Department of Agriculture, Forest Service General Technical Report NE-186.

Moll, G., 1989. The state of our urban forest. American Forests 95, 61-64.

Neal, C., Lass, D.A., 2014. Getting to the roots: production effects on tree root growth and morphology. American Nurseryman July, 10-14. 
Nowak, D., Crane, D., 2002. Carbon storage and sequestration by urban trees in the USA. Environmental Pollution 116, 381-389.

Nowak, D., McBride, J., Beatty, R., 1990. Newly planted street tree growth and mortality. Journal of Arboriculture 16, 124-129.

Nowak, D.J., Dwyer, J.F., 2007. Understanding the benefits and costs of urban forest ecosystems. In: Kuser, J.E. (Ed.), Handbook of urban and community forestry in the Northeast. Plenum Publishers, New York, pp. 11-25. doi:10.1007/978-1-40204289-8_2

Oliveira, S., Andrade, H., Vaz, T., 2011. The cooling effect of green spaces as a contribution to the mitigation of urban heat: a case study in Lisbon. Building and Environment 46, 2186-2194. doi:10.1016/j.buildenv.2011.04.034

Pinheiro, H.A., DaMatta, F.M., Chaves, A.R.M., Loureiro, M.E., Ducatti, C., 2005. Drought tolerance is associated with rooting depth and stomatal control of water use in clones of Coffea canephora. Annals of Botany 96, 101-108. doi:10.1093/aob/mci154

Reiger, R., Whitcomb, C.E., 1982. A system for improving root development and ease of digging field grown trees. Okla. Ag. Expt. Sta. Res. Rep. P-829 10-13.

Richardson-Calfee, L.E., Harris, J.R., 2005. A review of the effects of transplant timing on landscape establishment of field-grown deciduous trees in temperate climates. HortTechnology 15, 132-135.

Roman, L.A., Scatena, F.N., 2011. Street tree survival rates: Meta-analysis of previous studies and application to a field survey in Philadelphia, PA, USA. Urban Forestry \& Urban Greening 10, 269-274. doi:10.1016/j.ufug.2011.05.008 
Skiera, B., Moll, G., 1992. The sad state of city trees. American Forests March/April, 6164.

Starbuck, C., Struve, D.K., Mathers, H., 2005. Bareroot and balled-and-burlapped red oak and green ash can be summer transplanted using the Missouri gravel bed system. HortTechnology 15, 122-127.

Stobbart, M., Johnston, M., 2012. A survey of urban tree management in New Zealand. Arboriculture \& Urban Forestry 38, 247-254.

Struve, D.K., 2009. Tree establishment: A review of some of the factors affecting transplant survival and establishment. Arboriculture \& Urban Forestry 35, 10-13.

Struve, D.K., 1993. Effect of copper-treated containers on transplant survival and regrowth of four tree species. Journal of Environmental Horticulture 11, 196-199.

Struve, D.K., 1990. Root regeneration in transplanted deciduous nursery stock. HortScience 25, 266-270.

Struve, D.K., Burchfield, L., Maupin, C., 2000. Survival and growth of transplanted large- and small-caliper red oaks. Journal of Arboriculture 26, 162-169.

Sundström, E., Keane, M., 1999. Root architecture, early development and basal sweep in containerized and bare-rooted Douglas fir (Pseudotsuga menziesii). Plant and Soil 217, 65-78. doi:10.1023/A:1004693031375

Thompson, J.R., Nowak, D.J., Crane, D., Hunkins, J., 2004. Iowa, U.S., communities benefit from a tree-planting program: characteristics of recently planted trees. Journal of Arboriculture 30, 1-9. 
Tubby, K.V., Webber, J.F., 2010. Pests and diseases threatening urban trees under a changing climate. Forestry 83, 451-459. doi:10.1093/forestry/cpq027

van den Berg, M., Wendel-Vos, W., van Poppel, M., Kemper, H., van Mechelen, W., Maas, J., 2015. Health benefits of green spaces in the living environment: A systematic review of epidemiological studies. Urban Forestry \& Urban Greening doi:10.1016/j.ufug.2015.07.008

Warren, S.L., Blazich, F.A., 1991. Influence of container design on root circling, top growth and post-transplant root growth on selected landscape species. Journal of Environmental Horticulture 9, 141-144.

Watson, G., 1985. Tree size affects root regeneration and top growth after transplanting. Journal of Arboriculture 11, 37-40.

Watson, G., Himelick, E., 2013. The practical science of planting trees. International Society of Arboriculture, Champaign, IL.

Watson, T.W., 2005. Influence of tree size on transplant establishment and growth. HortTechnology 15, 118-122.

Weicherding, P.J., Giblin, C.P., Gillman, J.H., Hanson, D.L., Johnson, G.R., 2007. Mechanical root-disruption practices and their effect on circling roots of pot-bound Tilia cordata Mill. and Salix alba L. "Niobe.” Arboriculture \& Urban Forestry 33, 43-47.

Wells, C., Townsend, K., Caldwell, J., Ham, D., Smiley, E.T., Sherwood, M., 2006. Effects of planting depth on landscape tree survival and girdling root formation. Arboriculture \& Urban Forestry 32, 305-311.

Yin, J., Bassuk, N.L., Olberg, M.W., Bauerle, T.L., 2014. Fine root hydraulic 
conductance is related to post-transplant recovery of two Quercus tree species.

Journal of the American Society of Horticultural Science 139, 649-656. 


\section{Figure Legends}

Fig. 1. Three container designs, L-R: Superoots ${ }^{\circledR}$ Air-Pot $^{\mathrm{TM}}$ (The Caledonian Tree Company, Pathhead, UK), Quadro antispiralizzante (Bamaplast, Massa e Cozzile, IT), and traditional rigid container (Cultistop; ARCA spa, Osio Sotto, IT), (Photo credit: Amoroso et al., 2010)

Fig. 2. Flexible, In-ground Fabric (IGF) containers, which can also be implemented as an above-ground production alternative.

Fig. 3. Betula nigra root systems (L-R) harvested from the rigid liner pot of a Pot-in-Pot (PIP) system, In-ground Fabric (IGF) system and Balled \& Burlapped (BNB).

Fig. 4. Deformed, stem-girdling roots of CG (container-grown), mature Acer rubrum observed after air-spading. Note specimen was installed too deeply.

Table 1. Nursery Production System Advantages and Disadvantages

Literature cited: ${ }^{1}$ Appleton $1989 ;{ }^{2}$ Appleton $1995 ;{ }^{3}$ Amoroso et al., 2010; ${ }^{4}$ Blessing and Dana, 1987; ${ }^{5}$ Buckstrup and Bassuk, 2000; ${ }^{6}$ Gilman, 2001; ${ }^{7}$ Gilman et al., 2010a;

${ }^{8}$ Gilman et al., 2010b; ${ }^{9}$ Green et al., 2015; ${ }^{10}$ Harris and Bassuk, 1993; ${ }^{11}$ Harris and Bassuk, 1994; ${ }^{12}$ Harris and Gilman, 1993; ${ }^{13}$ Lass and Neal, 2014; ${ }^{14}$ Lynch, 1995;

${ }^{15}$ Mathers et al., 2007; ${ }^{16} \mathrm{Neal}$ and Lass, 2014; ${ }^{17}$ Reiger and Whitcomb, 1982;

${ }^{18}$ Richardson-Calfee and Harris, 2005; ${ }^{19}$ Struve, $1993 ;{ }^{20}$ Struve, $2009 ;{ }^{21}$ Warren and Blazich, 1991; ${ }^{22}$ Watson and Himelick, 2013; ${ }^{23}$ Yin et al., 2014 
Figures

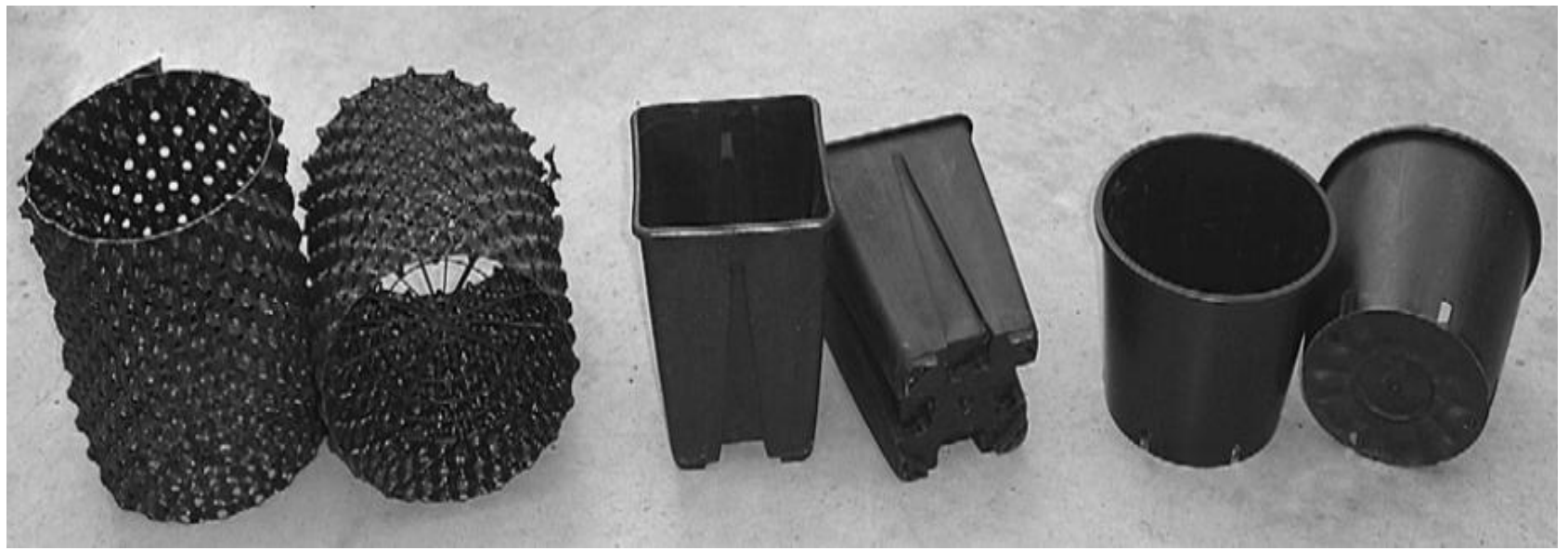

Fig. 1. 


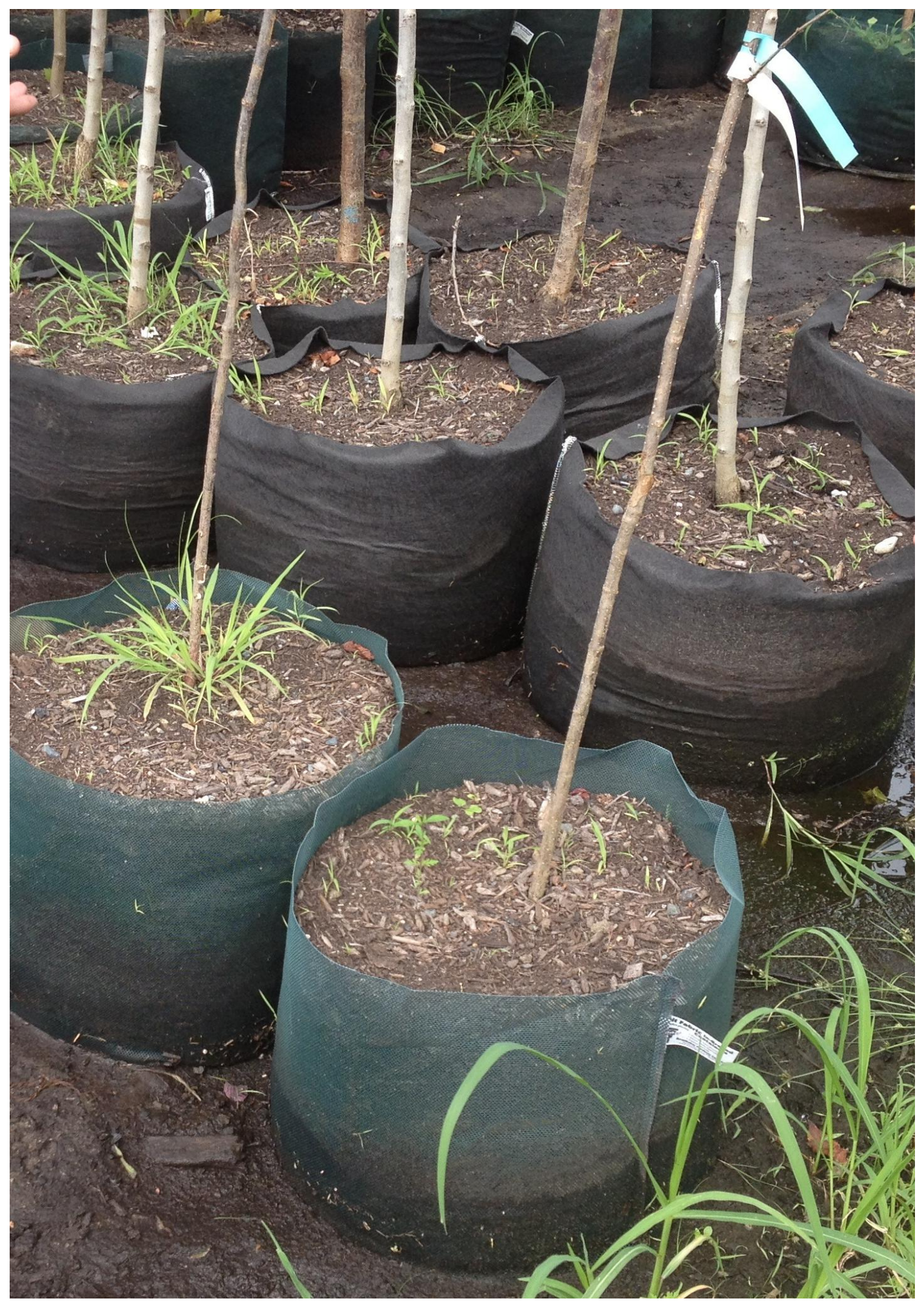

Fig. 2. 


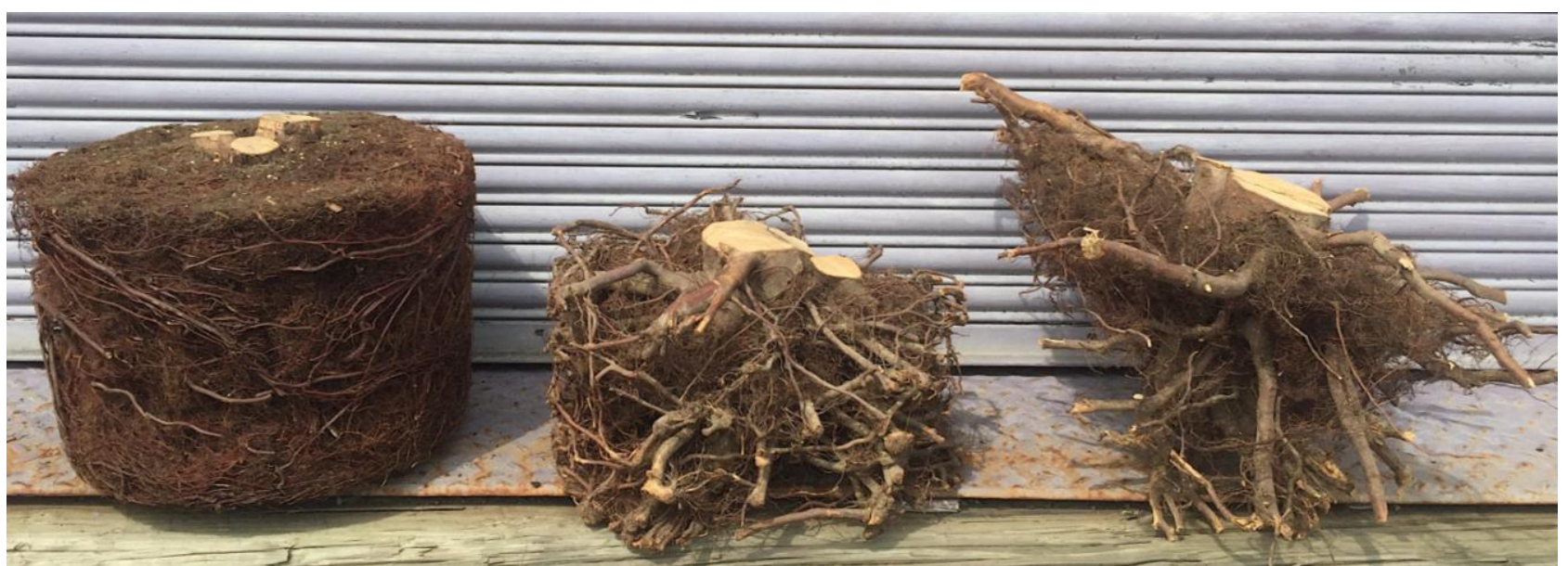

Fig. 3.

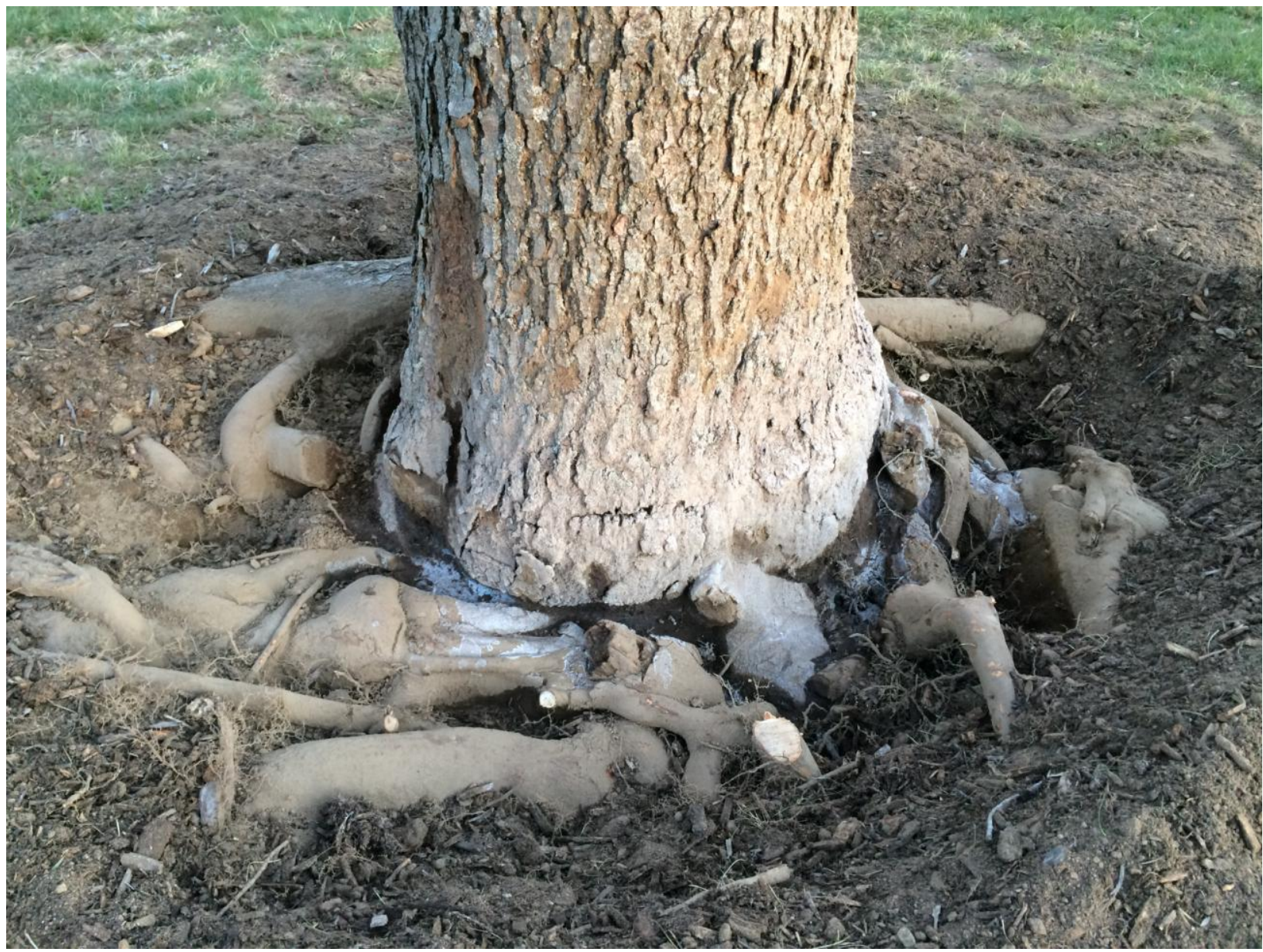

Fig. 4. 


\begin{tabular}{|c|c|c|}
\hline $\begin{array}{c}\text { Production } \\
\text { System }\end{array}$ & Advantages & Disadvantages \\
\hline $\begin{array}{l}\text { Container- } \\
\text { Grown } \\
\text { (CG) }\end{array}$ & 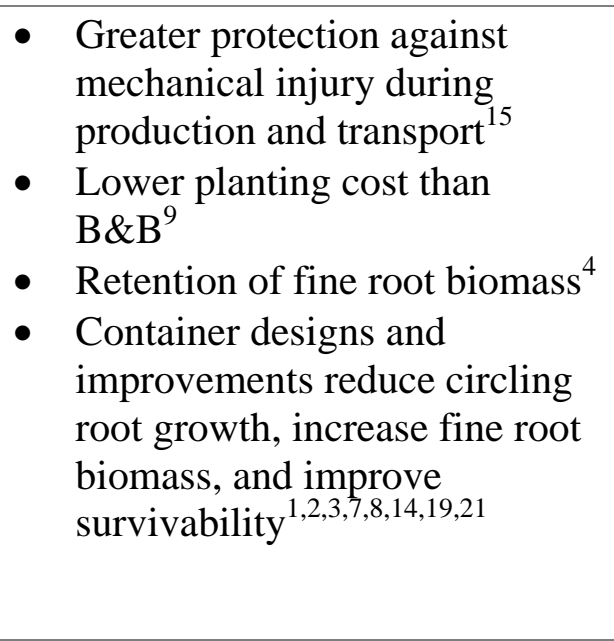 & 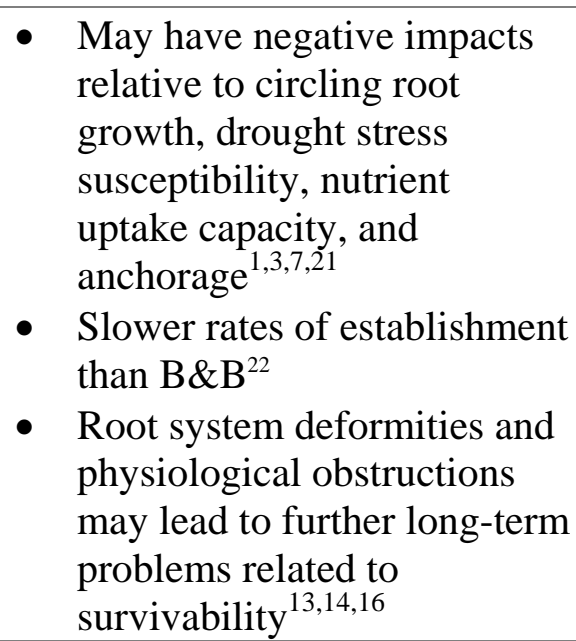 \\
\hline $\begin{array}{c}\text { Field- } \\
\text { grown: } \\
\text { Root Ball- } \\
\text { Excavated } \\
\text { and } \\
\text { Burlap- } \\
\text { Wrapped } \\
\text { (B\&B) }\end{array}$ & 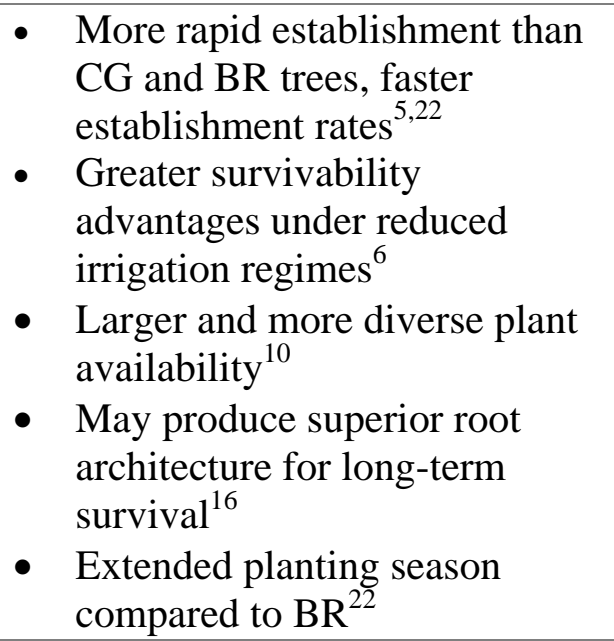 & $\begin{array}{l}\text { - } \begin{array}{l}\text { Loss of root biomass incurs } \\
\text { greater physiological } \\
\text { stress } 4,15,23\end{array} \\
\text { - } \begin{array}{l}\text { Higher cost of harvesting and } \\
\text { installation than CG and } \\
\text { BR }\end{array} \\
\text { - } \text { Removal of soil from } \\
\text { production field is } \\
\text { environmentally } \\
\text { damaging }{ }^{13,16} \\
\text { - More prone to mechanical } \\
\text { injury during production, } \\
\text { harvesting, and installation }\end{array}$ \\
\hline $\begin{array}{l}\text { Field- } \\
\text { grown: } \\
\text { Bare-Root } \\
\text { Harvested } \\
\text { (BR) }\end{array}$ & $\begin{array}{l}\text { - } \\
\text { - } \\
\text { Decreased irrigation use } \\
\text { during production }{ }^{12,17,18} \\
\text { - } \quad \text { Lower cost of transportation } \\
\text { and installation than B\&B and } \\
\text { CG systems } \\
\text { - } \text { Improved BR production }^{5} \\
\text { methods, such as Missouri } \\
\text { grave bed, can improve }^{\text {survival }}\end{array}$ & $\begin{array}{l}\text { May experience reduced } \\
\text { establishment rates }{ }^{20} \\
\text { More vulnerable after } \\
\text { harvesting, requires more } \\
\text { irrigation or root-dipping } \\
\text { treatment to prevent root } \\
\text { desiccation before planting } \\
\text { Restricted planting season } \\
\text { and limited plant material } \\
\text { availability }{ }^{11,20,22}\end{array}$ \\
\hline
\end{tabular}

Table 1. 